Кірпічніков Ю. А., к.т.н.;

Федорієнко В. А.;

Головченко О. В.;

Андрощук О. В.

Центр воєнно-стратегічних досліджень Національного університету оборони України імені Івана Черняховського, Київ

\title{
Аналіз рамкових архітектур побудови інформаційних систем НАТО та визначення особливостей архітектури C4ISR
}

Резюме. Стаття розкриває особливості архітектури C4ISR та іï роль для Збройних Сил України. Розглянутий ретроспективний аналіз сучасних рамкових архітектур воєнного призначення, які використовуються в НАТО. Наведені підходи таксономії НАТО, які необхідні для досягнення системної відповідності концепції рамкової архітектури.

Ключові слова: рамкова архітектура, C4ISR, таксономія.

Постановка проблеми. На сьогодні в Міністерстві оборони (МО) України та Збройних Силах (3С) України триває процес розвитку та впровадження новітніх інформаційних технологій. 3 огляду на необхідність збереження напрацювань Системного проекту Єдиної системи управління Збройними Силами України [1], урахування стандартів НАТО із дотриманням інтересів МО України та пріоритетів розвитку ЗС України, була розроблена Дорожня карта щодо створення інформаційної інфраструктури МО України. Одним із пунктів Дорожньої карти $\epsilon$ формування програм зі стандартизації інформаційної інфраструктури МО України на основі міжнародних стандартів та підходів НАТО.

Водночас, ці наміри підтверджуються положеннями, викладеними в Указі Президента України "Про рішення Ради національної безпеки і оборони України від 20 травня 2016 року "Про Стратегічний оборонний бюлетень України” [2], а саме, у другому розділі, який присвячений системі управління силами оборони. У ньому йдеться про створення до 2020 року національної телекомунікаційної мережі, модернізації та переведення на сучасні цифрові технології системи спеціального зв'язку, відомчих інформаційнокомунікаційних мереж та систем зв'язку пунктів управління органів державної влади, а також створення автоматизованої системи C4ISR (Command, Control, Communications, Computers, Intelligence, Surveillance and
Reconnaissance) складових сил оборони, яка відповідає стандартам, доктринам i рекомендаціям НАТО на всіх рівнях управління (тактичному, оперативному та стратегічному) із визначеною специфікою базових можливостей. У Бюлетені також наголошено на врахуванні сумісності системи управління військами і зброєю із системами ресурсного забезпечення.

При створенні такої складної системи важливо визначитися із суттю, архітектурою та місцем у загальному переліку різних концептуальних підходів. Тому, проведення аналізу так званих рамкових архітектур (Architecture Framework), що об’єднують основні принципи, концепції, правила, шаблони, інтерфейси, стандарти побудови інформаційних систем НАТО та визначення особливостей архітектури C4ISR для висвітлення шляхів адаптації у MO України $\epsilon$ актуальною задачею.

Ступінь розробленості проблеми. Аспекти застосування рамкових архітектур, прийнятих у цивільному секторі, при побудові архітектури підприємства для військової сфери зазначені в джерелах [3-5]. Ретроспектива розвитку військових рамкових архітектур за останні тридцять років наведена у роботі [6]. Загальні принципи рамкових архітектур, прийнятих у НАТО, представлені в [7, 8]. У роботі [9] розкрите поняття архітектури підприємства на основі аналізу сучасних світових підходів до проектування рамкових архітектур та визначене місце інформаційної інфраструктури МО України. 
Метою статті є визначення поняття та особливостей архітектури C4ISR на основі аналізу провідних підходів до проектування рамкових архітектур у НАТО.

Виклад основного матеріалу. У провідних країнах світу вже давно розробляється цілий пласт проблем, пов'язаних 3 архітектурним підходом до складних організаційно-технічних об'єктів, таких як підприємство та інформаційні системи підприємства. Згідно найбільш загальним визначенням, під терміном “підприємство" мається на увазі комплексна система культурних, технологічних i процесних компонент, організованих для досягнення цілей організації. Застосовувати архітектурні підходи можна як до цілого підприємства або його підрозділу, так і до окремої прикладної системи.

Архітектура підприємства (Enterprise Architecture - EA) $\epsilon$ одним 3 інструментів організаційних змін, як для всього підприємства в цілому, так і тієї частини організації, яка відповідає за інформаційні технології [10].

У світовій практиці існують індустріальні стандарти для опису архітектури підприємства, прийняті такими організаціями, як Інститут інженерів електрики та електроніки (IEEE - Institute of Electrical and Electronics Engineers), Міжнародна організація стандартизації (ISO - International Organization for Standardization), The Open Group тощо.

До переваг архітектурного підходу за TOGAF (The Open Group Architectural Framework) [4] відносять: поліпшення $\mathrm{i}$ підвищення

продуктивності функціональних процесів; зменшення витрат;

підвищення ефективності операційної функціональної діяльності;

підвищення ефективності управління; зменшення ризиків;

підвищення ефективності IT-підрозділів; підвищення продуктивності роботи

користувачів; підвищення інтероперабельності

(функціональної взаємодії); зменшення вартості підтримки

життєвого циклу;

поліпшення характеристик безпеки; підвищення керованості.

У НАТО також використовують архітектурні підходи до впровадження інформаційних систем. Поняття "C4ISR" визначається як архітектура та конщепйія взаємодї складових системи бойового управління оперативного та оперативностратегічного рівня.

Apxiтектура C4ISR означає підхід, який передбачає комплексну інтеграцію засобів оперативно-стратегічної розвідки, спостереження та військової розвідки (Intelligence, Surveillance and Reconnaissance) i3 системами управління, контролю, зв'язку та обчислювальними засобами (Command, Control, Communication, Computers) [7] в єдиному інформаційному середовищі, яке, у свою чергу, забезпечує інтеграцію навігаційної, загальногеографічної та тактичної інформації в єдиній географічній системі координат. Разом перелічені інтеграційні процеси дають змогу реалізовувати мережецентричну архітектуру управління військами, яка у деякій мірі змінила підходи до ведення бойових дій за рахунок використання принципів мережецентричності.

C4ISR також розуміють як єдиний масштабний програмно-технічний комплекс. У назві C4ISR (командування, контроль, зв'язок, комп'ютери, розвідка, спостереження, рекогносцировка) перераховані функції, які мають бути автоматизованими. Тому системи, побудовані за подібною концепцією, носять назву інтегрованих систем розвідки та управління.

На відміну від C2+ або C2SR (Command, Control, Surveillance, Reconnaissance) концепції тактичного рівня, де самостійною одиницею $\epsilon$ окремий солдат чи військова техніка, у C4ISR ці одиниці стають членами тактичної мережі або бойового інтернету.

Архітектури та концепції C4ISR i C2+ передбачають створення інформаційного середовища, яке дає змогу:

автоматично визначати положення i переміщення своїх підрозділів (автоматично відображається на електронних картах);

автоматично визначати положення противника i його переміщення (також відображається на електронних картах);

автоматично обирати маршрути руху; автоматично давати цілевказівки засобам вогневого ураження;

автоматично інформувати свої підрозділи про дії i місцезнаходження їх сусідів i противника.

Ці можливості доступні на оперативному i тактичному рівнях. До зазначених пунктів для C4ISR, тобто оперативного рівня, слід додати: повна автоматизація збору інформації та iii обробка; 
автоматизоване надання варіантів рішення командира, заснованих на автоматично отриманих розвідданих, а також на інформації про сили i засоби, що $\epsilon$ в розпорядженні;

моделювання бою i його можливих результатів;

пропозиції часткових рішень для командира в ході бою, засновані на поточній ситуації.

Таким чином, різниця між тактичним i оперативним рівнями систем полягає в можливості автоматизації прийняття рішення, моделюванні бою і прогнозуванні результатів.

Крім того, C4ISR має розширену автоматизацію для логістики. Облік витрат необхідних засобів системою ведеться постійно. Дані про потреби підрозділів у поповненні боскомплекту, засоб логістичного забезпечення, необхідні запчастини та інше - обробляються безперервно, що дає змогу своєчасно здійснювати поставки всього необхідного для ведення успішних бойових дій.
Прикладом реалізації C4ISR для тактичного рівня $\epsilon$ програмне забезпечення DAP (Digital Army Program), що розробляють американські компанії-виробники Northrop Grumman та Lockheed Martin. Метою DAP $€$ створення єдиного інформаційного поля, що забезпечує ситуаційну обізнаність, автоматизацію управління, удосконалення оперативних можливостей i найбільш ефективне використання сил, засобів і ресурсів.

Ретроспективний аналіз. Становлення i розвиток C4ISR отримала у США в 1990-х роках i стала точкою відправлення для військових рамкових архітектур, до яких відносяться рамкові архітектури країн-членів HATO.

На рис. 1 наведено часову шкалу ключових етапів становлення архітектури

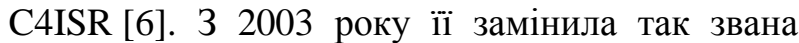
рамкова архітектура MO CШA - DoDAF (Department of Defence Architecture Framework) $[3,4]$.

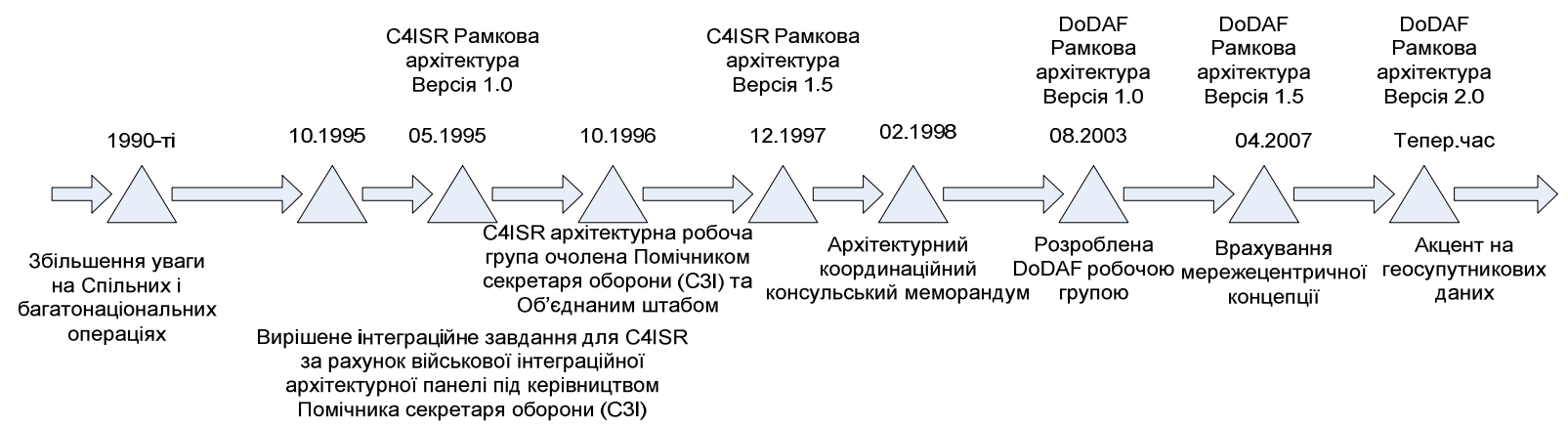

Рис. 1. Еволюція рамкової архітектури США від C4ISR до DoDAF v 2.0

В Альянсі використовують власний використовують власну рамкову архітектуру підхід - NATO Architecture Framework (NAF), Рамкову архітектуру Департаменту що базується на спеціальних відомчих Національної оборони Збройних Сил Канади підходах до проектування архітектури DoDAF DNDAF (Department of National Defence / та 3 використанням досвіду підприємств Canadian Armed Forces Architecture Framework). цивільного сектору TOGAF [4]. У МО Канади

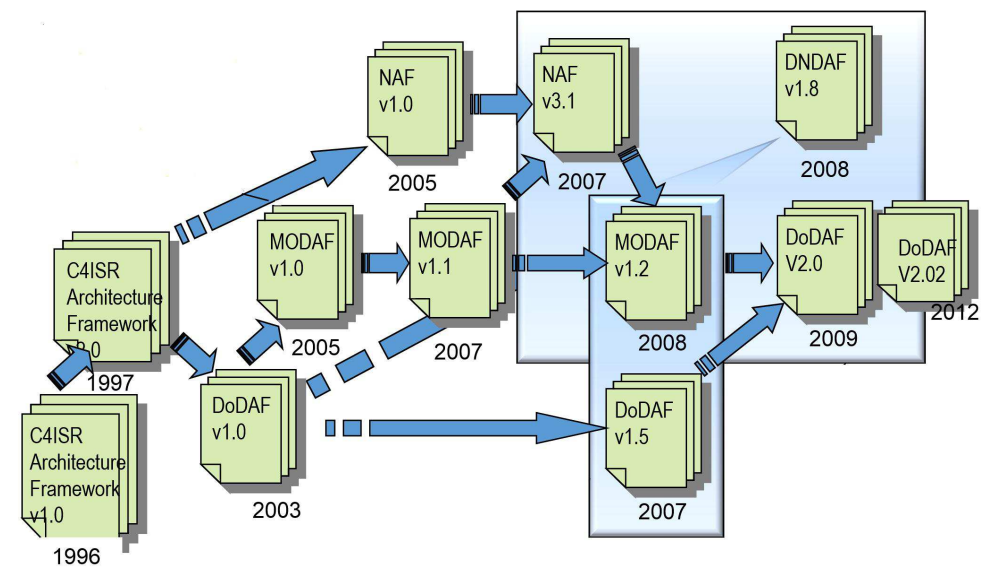

Рис. 2. Еволюція військових рамкових архітектур краӥн-членів та НАТО 
Нині архітектура МО США, що побудована на основі архітектури DoDAF y другому виданні (DoDAF v2.02) найбільш повно описана у відкритих джерелах, порівняно 3 іншими військовими архітектурами НАТО. Попередньо ця архітектура була узгоджена конструктивними елементами 3 Рамковою Архітектурою Міністерства оборони Великобританії (UK Ministry of Defence Architecture Framework, MODAF), 3 Рамковою Архітектурою НАTO (NATO Architecture Framework, NAF) та 3 Рамковою Архітектурою Відкритої Групи TOGAF, а вже потім ці елементи були адаптовані для використання в межах DoDAF. Ці узгодження 3 поточними версіями передових архітектур НАТО наведено на рис. 2 великим прямокутником.

Apхітектура DoDAF містить правила, настанови та інші керівні документи, які повинні використовуватися при розробленні та описі архітектур різних систем, що використовуються військовими відомствами США та НАТО. Усі вони розроблені для надання можливостей використання інформаційних технологій 3 точки зору швидкої мобілізації для виконання військових операцій i підвищення ефективності розроблення відповідних систем. Важливим аспектом цієї методики $є$ здатність забезпечувати порівняння, аналіз та інтеграцію архітектур систем, що одночасно використовуються різними функціональними підрозділами у географічно розподіленому організаційному середовищі. Зазначимо, що у систему C4ISR закладені спроможності до глобальної масштабованості [7].

На рис. 3 наведено структуру основних уявлень, що використовуються в DoDAF. Відповідно до цієї методики розглядається три різних уявлення (операційне, системне i уявлення технічних стандартів), які у сукупності описують архітектуру. Кожне 3 них використовується для відображення різних архітектурних характеристик і атрибутів, хоча між ними є певні перетини. Деякі з атрибутів об'єднують два різних уявлення, що забезпечує цілісність, єдність і однаковість в описі архітектури. Вважається, що найбільш корисним описом архітектури є "інтегроване", тобто те, що поєднує різні уявлення в описі систем.

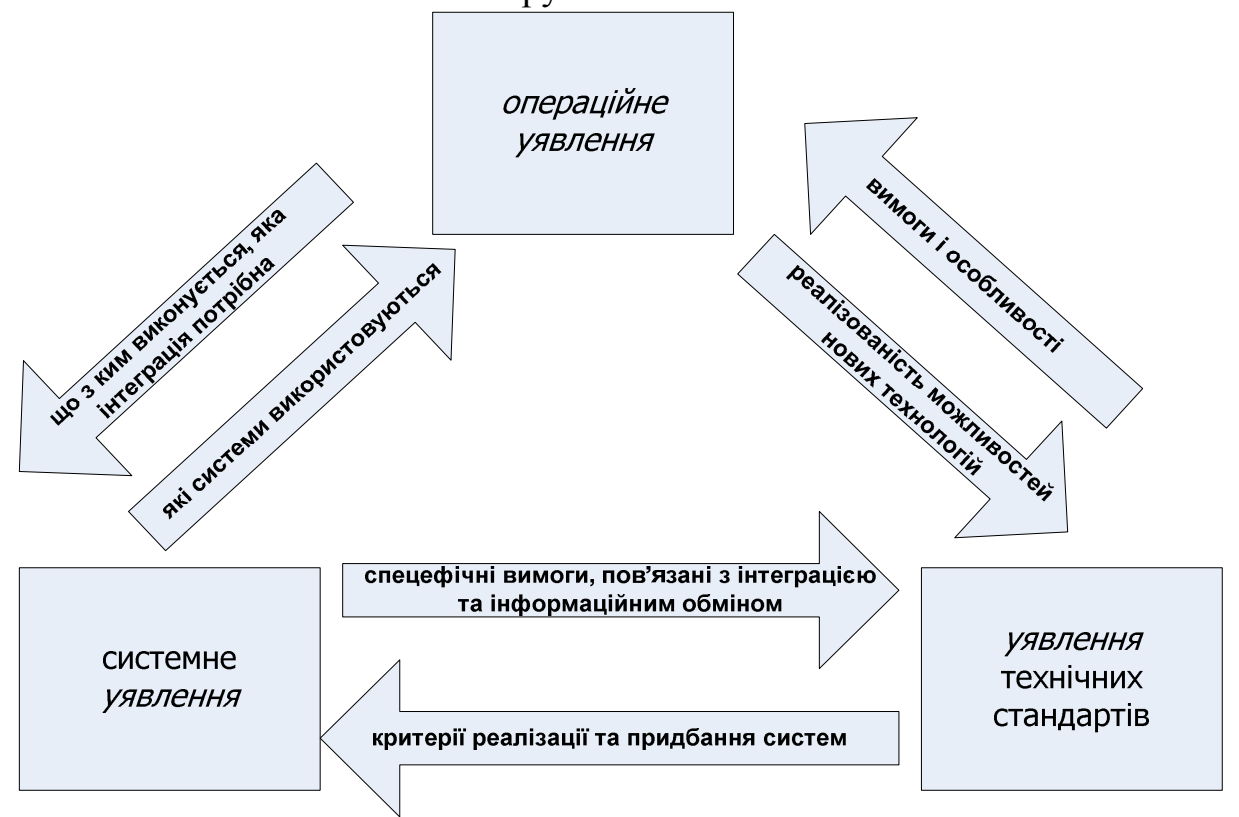

Рис. 3. Три основних уявлення, що використовуються в DoDAF

Операційне уявлення (відповідає за те, що треба виконати і хто це виконує) включає опис завдань i діяльності, операційних елементів та інформаційних потоків, які потрібні для діяльності міністерства оборони. Операція включає, як суто військові функціональні процеси, так i традиційні бізнес-процеси. Операційне уявлення містить опис (часто графічний), який включає: вузли виконання операцій і елементів; призначені завдання та активності; інформаційні потоки між вузлами. Операційне уявлення визначає: тип даних в інформаційному обміні; частоту інформаційного обміну; перелік завдань i активностей, які забезпечуються інформаційним обміном; характер інформаційного обміну.

Операційне уявлення відносно системного уявлення (див. рис. 3) диктує, які процедури $з$ ким виконуються, яка інтеграція потрібна. I у зворотному боці - системне 
уявлення диктує, які системи взагалі використовуються.

Системне уявлення відносно уявлення технічних стандартів диктує, які повинні бути специфічні вимоги, пов'язані з інтеграцією та інформаційним обміном. У зворотному боці уявлення технічних стандартів диктує критерії реалізації та придбання систем.

Уявлення технічних стандартів відносно операційного уявлення диктує вимоги i особливості. У зворотному боці - операційне уявлення диктує стан реалізованості можливостей нових технологій.

Системне уявлення (відповідає за зв'язок характеристик систем із задачами, що виконуються) включає текстові та графічні описи систем i зв'язків між ними, які використовуються для забезпечення виконання функцій міністерства. Системне уявлення описує зв'язок між системними ресурсами на операційному рівні. Ці системні ресурси підтримують операційні процеси і забезпечують інформаційний обмін між операційними вузлами.

Уявлення технічних стандартів (відповідає за визначення стандартів і угод) визначає мінімальний набір правил, якими керуються при створенні, забезпеченні взаємодії та налагодженні взаємозв'язків між частинами систем і елементами. Це уявлення забезпечує технічне керівництво, на основі якого базуються інженерні специфікації. Для цього створюються загальні блоки i розробляються лінійки продуктів.

Уявлення технічних стандартів включає наступні елементи описового документального забезпечення:

технічні стандарти;

угоди по реалізації технічних стандартів;

особливі умови при використанні стандартів;

правила i критерії, організовані у профілі, які використовуються при створенні систем і елементів.

Є певні аспекти, які мають відношення до всіх трьох уявлень архітектури. Ці загальні аспекти відображаються за допомогою загальних для всіх уявлень описів - текстових і графічних. Такі описи надають інформацію, що відноситься до архітектури в цілому, яка не підпадає під сферу відповідальності окремого уявлення. Вони задають масштаб, межі (або охоплення предметної області) i контекст архітектури. Контекст архітектури включає такі аспекти: доктрини, тактику і процедури;

цілі та бачення;

концепцію операцій;

сценарії;

умови зовнішнього середовища.

Найважливішим елементом i сильною стороною методики $€$ так звані архітектурні продукти. Це графічні, текстові, табличні описи, які створюються у процесі опису архітектури i фіксують характеристики, що стасуются процесу.

Будучи частиною опису архітектури, всі продукти, в тому числі і графічні, повинні містити пояснювальний текст. Наприклад, для графічних продуктів повинні бути вказані всі використовувані скорочення i пояснення стосовно їхнього змісту.

Всього для різних уявлень архітектури налічується понад 20 різних типів архітектурних продуктів: графічний високорівневий опис концепції операцій, модель операційних активностей, модель операційних правил, опис переходу між станами операцій, опис системних інтерфейсів тощо.

Таксономія С3. Заслуговує на увагу спрощений підхід до розроблення та проектування рамкових архітектур. Прикладом цього підходу $є$ опублікований класифікатор із розкриттям основ систематики і таксономії NATO C3 Classification Taxonomy [12]. 3a результатами конференції Integrated EA Conference 2012 було визнано, що у НАТО слід використовувати зазначений класифікатор в якості керівництва для досягнення системної відповідності C4ISR. Вiн $€$ інструментом синхронізації всіх видів функціональних можливостей за рахунок консультації, командування і управління (Consultation, Command and Control, C3). Також він $\epsilon$ ієрархічно класифікованим переліком сервісів комунікаційно-інформаційні системи (Communications and Information Systems, CIS) i адаптованим до практичної імплементації версіï NATO Architecture Framework.

Цей інструмент враховує стратегічну концепцію і політичне керівництво в рамках процесу військового планування НАТО (NATO Defence Planning Process) 3 традиційною CIS архітектурою.

Основними документами, що визначають принципи побудови та інтеграції CIS для підтримки всього спектра військових операцій є Об'єднуюча доктрина для комунікацій та інформаційних систем AJP-6 (Allied joint doctrine for communication and information 
systems) [13], та стандарт HATO - STANAG 2525. У цій доктрині описані характеристики CIS, загальна структура, ролі i відповідальності при їх розгортанні й експлуатації.

CIS середовище, за стандартами НАТО, повинне застосовуватися як сервісорієнтована архітектура (Service Oriented Architecture), що організовує програмне забезпечення у формі незалежних функціонально-замінних сервісів [7].

Сервіси і їх взаємодія описані у каталозі C3 Classification Taxonomy, при цьому, ïx реалізація здатна забезпечити інтероперабельність 3 іншими сервісами і зовнішніми системами. Об'єднані CIS можуть мати сервісну модель, що “будується" у рамках зазначеної єдиної промислової архітектури. Ця модель “інкапсулюе" інформаційні сервіси 3 необхідним рівнем якості.

Інформаційні сервіси в рамках таксономії С3 в себе включають:

комунікаційні сервіси (забезпечують передачу інформації між користувачами, терміналами, інформаційними системами);

інтеграційні сервіси (забезпечують загальну для всіх користувачів функціональність середовища: електронна пошта, зберігання даних, каталоги, ідентифікацію користувачів, друк, доступ до додатків тощо);

функціональні сервіси (забезпечують інформаційну підтримку виконання функціональних завдань користувачів: управління військами всіх рівнів, логістики, управління персоналом, озброєння тощо);

комунікаційні та базові сервіси (платформа для функціональних сервісів).

Для концептуальної міжнаціональної сумісності CIS HATO та нових країнпартнерів, існують розроблені стандартні підходи. Для систематики концепції застосовують принципи таксономії, що забезпечують єдність підходу, інтероперабельність при побудові і розвитку CIS. Таксономія вирішує наступні завдання:

"фіксує" технологічні залежності підсистем;

пов'язує предметні (функціональні)

області з технічними сервісами;

спрощує планування, розгортання i модернізацію CIS;

дає можливість “складання" елементів CIS з готових стандартних компонент.
Актуальність створення інформаційної інфраструктури МО України на основі методологіï C4ISR підкреслює той факт, що одним із пріоритетів національних інтересів України сьогодні $\epsilon$ інтеграція у євроатлантичний простір, поглиблення співробітництва 3 НАТО. Відповідно до Воєнної доктрини України, Стратегічного оборонного бюлетеня України [1], одними 3 основних завдань $€$ впровадження стандартів НАТО, досягнення сумісності всіх структур 3С України та їх спецпідрозділів із силами та засобами відповідних структур країн-членів НАТО, інтеграція із системою командування та контролю C4ISR.

Висновки. У роботі було визначено поняття, зміст та особливості архітектури C4ISR за рахунок проведення аналізу провідних підходів до проектування рамкових архітектур побудови інформаційних систем НАТО. Проведений ретроспективний аналіз сучасних рамкових архітектур воєнного призначення, які використовуються в НАТО, а також розглянуті підходи відповідно таксономії С3, які необхідно враховувати при побудові інформаційної інфраструктури МО України.

Подальші дослідження слід присвятити аналізу системного уявлення рамкових архітектур НАТО.

\section{СПИСОК ВИКОРИСТАНОЇ ЛІТЕРАТУРИ}

1. Артюх В. М. Современный этап разработки и строительства Единой автоматизированной системы управления Вооруженными Силами Украины / В. М. Артюх, В.К. Медведев // Оборонный вестник. - 2012. - № 1. - С. 15-24. Режим http://defpol.org.ua/site/files/OV 12012 rus.pdf.

2. Про рішення Ради національної безпеки і оборони України від 20 травня 2016 року "Про Стратегічний оборонний бюлетень України" [Електронний ресурс]: указ [видано Президентом України 06 червня 2016 р. №240/2016]. - Режим доступу: http://www.president.gov.ua/ documents/2402016-20137.

3. DoD Architecture Framework Version 1.5. Volume I: Definitions and Guidelines [Electronic Resource] // Chief Information Officer U.S. Department of Defense. - 2007. - Mode of access: http://dodcio.defense.gov/Portals/0/Documents/DOD AF/DoDAF_Volume_II.pdf.

4. The DoDAF Architecture Framework Version 2.02 [Electronic Resource] // Chief Information Officer U.S. Department of Defense. - 2011. - Mode of access: http://cionii.defense.gov/sites/ dodaf20/index.html.

5. C4ISR Architecture Framework Version 2.0 [Electronic Resource] // C4ISR Architecture Working 
Group U.S. Department of Defense. - 1997. - Mode of access: http://www.afcea.org/education/ courses/archfwk2.pdf.

6. Szlachta B. Nato Architecture Framework. NATO Operational View. Training Material [Electronic Resource] / Bernard Szlachta // Noble Prog. - 2016. - Mode of access: http://trainingcoursematerial.com/index.php?title=Nato_Architectu re_Framework_(NAF)_-_3.3_-_NATO_

Operational_V ew\&printable=yes.

7. D'hollande G. AGENCY TECHNICAL DIRECTIVE 00.01.02. NATO C4ISR System Design Principles [Electronic Resource] / Georges D'hollande // NATO C3 Agency. - 2011. - Mode of access:

http://www.pegasim.com/CITT/2_External_Referenc e_Documents/NC3A/ATD-00.01.02 \%20$\%$ 20NATO\%20C4ISR\%20System\%20Design \%20Pr inciples\%20-\%20PUBLIC.pdf.

8. Bridging the Gap. European C4ISR Capabilities and Transatlantic Interoperability [Electronic Resource] / G. Adams, G. Ben-Ari, J. M. Logsdon, R. A. Williamson // The George Washington University. 2004. - Mode of access: https://www.files.ethz.ch/isn/140166/DTP\%205\%20 C4ISR\%20Gap.pdf.

9. Голобородько М. Ю. Теоретичні підходи щодо визначення місця інформаційної інфраструктури Міністерства оборони України у розумінні рамкових архітектурних методологій / М. Ю. Голобородько, В. А. Федорієнко, Ю. А. Кірпічніков [та ін.] // Збірник наукових праць Центру воєнно-стратегічних досліджень Національного університету оборони України імені Івана Черняховського. - 2016. - № 3(58). - С. 136-141.

10. Данилин А. Архитектура предприятия [Електронний ресурс] / А. Данилин, А. Слюсаренко // Национальный Открытый Университет "ИНТУИТ”. - 2007. - Режим доступа:

http://www.intuit.ru/goods_store/ebooks/8292.

11. ANSI/IEEE 1471 and Systems Engineering [Electronic Resource] /Mark W. Maier, David Emery, Rich Hilliard // The Journal of the International Council on Systems Engineering. - Mode of access: https://pdfs.semanticscholar.org/3932/efb591c25806fb 285620e2a6984d0c42f383.pdf.

12. NATO C3 Classification Taxonomy [Electronic Resource].- Mode of access: https://www.yumpu.com/en/document/view/24003661 /c3-classification-taxonomy-nci-agency-nato.

13. AJP-6. Allied Joint Doctrine For Communication And Information Systems [Electronic Resource].Mode of access: https://www.gov.uk/government/uploads/ system/uploads/attachment_data/file/ 200016/20110401-ajp6_cis_secured.pdf.

Стаття надійшла до редакції 27.01.2017

Кирпичников Ю. А., К.Т.н.;

Федориенко В. А.;

Головченко А. В.;

Адрощук О. В.

Центр военно-стратегических исследований Национального университета обороны Украины имени Ивана Черняховского, Киев

Анализ рамочных архитектур построения информационных систем НАТО и определение особенностей архитектуры C4ISR

Резюме. Статья раскрывает особенности архитектуры C4ISR и ее роль для Вооружённых Сил Украины. Рассмотренный ретроспективный анализ современных рамочных архитектур военного назначения, которые используются в НАТО. Приведены подходы таксономии НАТО, которые необходимы для достижения системного соответствия концепции рамочной архитектуры.

Ключевые слова: рамочная архитектура, C4ISR, таксономия.

\section{Y. Kirpichnikov, Ph.D;}

V. Fedorienko;

A. Golovchenko;

O. Androshchuk

Center for Military and Strategic Studies National Defence University of Ukraine named after Ivan Chernyhovsky, Kyiv

Analysis of Architecture Frameworks for building information systems of NATO and determine architectural features C4ISR

Resume. The article exposes the features of architecture of C4ISR and her role for the Armed Forces of Ukraine. Considered retrospective analysis of modern scope architectures of military-oriented, that is used in NATO. Approaches over are brought taxonomies of NATO, that is needed for the achievement of system accordance of conception of scope architecture.

Keywords: architecture framework, C4ISR, taxonomy. 